\title{
Does Tourism Change Tourist Attitudes (Prejudice and Stereotype) towards Local People?
}

\author{
Sedat ÇELIK \\ Şırnak University.
}

Received: 13 March 2019. Revision received: 6 May 2019. Accepted: 6 May 2019

\begin{abstract}
The main goal of this study is to determine whether attitudes (prejudices and stereotypes) of domestic tourists towards South-easterners change after their travel experiences. Additionally, whether the levels of contact (the number of overnights stay, travel type, the number of arrivals at destination) with the local people have any effects on changes of attitude was determined to be sub-goals of this study. In this study, quantitative data analysis method was used. The research was designed as a non-experimental mixed pattern. The pre-holiday and post-holiday attitudes of domestic tourists arriving in Gaziantep and Şanlıurfa were investigated using the questionnaire (n: 386). Additionally, data was gathered during the process of study from people who have never visited the Southeast to create a comparison group (n: 252). Factors analysis, frequency, ANOVA and t-test analyses were applied to the gathered data. As a result of analyses, the prejudices of participants who have never come to the Southeast have been higher. Also, positive changes were determined in the attitudes (prejudices, positive attitudes) of people who have undergone experiences of travel. However, it was also revealed that there are no statistically significant differences that are dependent on factors of contact variables (namely the type of travel, the number of overnights stays, and the number of arrivals at the destination). This research is important as it contributes to the gap in the tourism and social psychological area and explains the attitudes of tourists towards the local people. This research is also important in establishing whether tourism can be used as a tool for decreasing intercommunal problems.
\end{abstract}

Key Words: Tourism, Peace, Prejudice, Stereotype, Attitude Changes

\section{JEL Classification: L83}

\section{Introduction}

Due to people having attitudes such as stereotypes or prejudices against people who aren't like them, it becomes difficult for societies to grow closer and get to know each other. This situation causes societies to keep their distance with one other and creates a sense of hostility between them (Choi, Lee, Lee \& Kim, 2017; Ming, 2018). One of the most important ways of this preventing situation is to increase the contact between societies and allowing them to know each other (Allport, 1954). One of the most important tools in ensuring this contact is the sector of tourism, which creates opportunities for traveling and getting familiar with other peoples and cultures (Zaei \& Zaei, 2013). 
The sector of tourism continues to grow with each passing day (UNWTO, 2018) and negative or positive social, environmental, economic, political, cultural and socialpsychological effects (Rezaei, 2017; Çelik \& Uygur, 2017; Amalu, Otop, Duluora, Omeje, \& Emeana, 2018; Pong But, \& Ap, 2017) are shaping tourism destinations. Studies that show the social-psychological effects of tourism (Grothe, 1970; Pearce, 1980; Pizam, Jafari \& Milman, 1991; Günlü et al., 2015; Ajanovic, Çizel \& Çizel, 2016; Çelik, 2018; Ming, 2018) are of special importance for tourism and social psychology. In these studies, the role that tourism plays on the transformations of the attitudes (such as prejudices and stereotypes) that constitute the building blocks of social psychology (Allport, 1954) was the preferred point of focus. In the literature, the consensus is that tourism plays an important role in understanding social relations and cultural distances, intergroup relations, travel experiences and the attitudes of tourists (Fan, Zhang, Jenkins, \& Lin, 2017).

The goals of this study are to determine whether attitudes (prejudice and stereotype) of domestic tourists towards South-easterners change after their travel experiences, whether people who have never visited Southeast have differences in attitude than those who have, and whether the level of contact (type of travel, the number of overnights stays, and the number of arrival at the destination) with the local people affect the changes in attitude. The social prejudices of domestic tourists who have visited the provinces of Gaziantep and Şanlıurfa, which are in located the Southeast Anatolia Region, towards South-easterners before and during their vacations were measured using the survey technique. Additionally, during the research process, a comparison group was formed by asking the same scale questions to people who have never visited the Southeast. In this regard, the research was designed as a non-experimental mixed pattern (Büyüköztürk 2014). There are studies that focus on tourism's effect on changes in attitude. Moreover, there is a limited amount of studies that demonstrate what factors are effective in the changes of attitude. The main focus of this study is determining whether tourism changes attitudes or not. Furthermore, whether the social contact levels, such as the type of travel (individual or package), the amount of time spent at the destination, and the amount of times the destination was visited, creates any differences or not was also established. Therefore, it can be said that this research is important as it contributes to the gap in the literature and explains the attitudes of tourists towards the local people. This research is also important in establishing whether tourism can be used as a tool for decreasing intercommunal problems.

\section{Literature review}

\subsection{Concept of Attitude}

Attitude is seen as "a structure which predates behaviour and guides our decisions for action" (Hogg \& Vaughan, 2007:174). Kağıtçıbaşı \& Cemalcılar (2014:129) defined attitude as "an inclination that is attributed to a person, which forms his thoughts, emotions, and behaviours towards a psychological object in a regular way". Although there are many other similar definitions, it is possible to define attitude as "statements towards objects, people or events that include expressions such as negative or positive, good-bad, nice-not nice and beneficial-harmful" (Fishbei \& Azjen, 1975; Aronson, Wilson, \& Akert, 2012:356). There are many factors that play a role in the formation of attitudes such as genetic, physiological, environmental, and personality (Hortaçsu, 2012; Aronson et al., 2012). 
Attitudes consist of cognitive, emotional and behavioural elements (Jain, 2014). The cognitive dimension of attitudes forms stereotypes, the emotional dimension forms the prejudices and behavioural dimension forms discrimination. There may be positive or negative attitudes towards a society, group or person or object. While negative attitudes create prejudices, stereotypes express characteristics that are attributed to a group of people. Indeed, according to Allport (1954), prejudice is "having hostile or negative attitudes towards a group of distinguishable people based solely on their membership to that group". Stereotypes can be defined as "beliefs on the characteristics of a certain social group" (Stanciu et al., 2018).

Researches that focus on the subject of attitudes have always been important. The reason for this is that attitudes are investigated to allow the prediction of human behavior. At this point, whether attitudes create behaviours was investigated (LaPierre, 1934; Minard, 1952) and it has been determined that attitudes do not always create behaviours. This is due to the fact that sometimes, people, for a variety of reasons (social pressure, group belonging, personality, etc.), can choose to hide-repress their attitudes (Hogg \& Vaughan, 2007).

\subsection{Tourism and Attitude Change}

Attitudes are very difficult things to change. However, Allport (1954) has claimed in some situations, prejudices can be reduced by establishing contact between groups. These situations were determined as groups having equal status, existence cross-group cooperation, common goals, and the support of an authorized individual. At this point, despite the creation of conditions stated by Allport being very difficult in the tourism sector, tourism, by enabling people from different cultures and nationalities to come together, is effective in creating world peace by changing prejudices and stereotypes (Var, Brayley, \& Korsay, 1989; Pratt \& Liu, 2015; Farmaki, 2017). According to Tomljenovic (2010), factors such as the amount of time spent in the destination, the number of activities, the purpose of visit, satisfaction with the vacation, characteristics of the destination, cultural distance, language and the intensity of the pre-vacation attitude are influential in changes of attitude in the tourism sector.

Tourism is not only sector that has an economic effect, but it also is a tool that procures interaction between societies. Tourism is a mind-opening experience, which teaches people that the world is not made up of a single model of living and other models of living exist(Wintersteiner \& Wohlmuther, 2014). Many studies have demonstrated that this experience changes the attitudes of people.

In his study Ming (2018) has presented a group of 26 Thai individuals an openended survey about their attitudes towards Chinese tourists. As a result of the survey, it was determined that there are positive attitudes such as good, generous, educated, etc. towards Chinese tourists in addition to some negative ones such as disobeying traffic rules, not respecting traditions and talking loudly. In the study of Sirakaya-Turk, Nyaupane \& Uysal (2014), the prejudices of 371 German tourists towards Turks at the start and the end of their vacation, and 4 months after it, were questioned and the results were compared. It was determined German tourists had more negative prejudices towards Turks than those whose prejudices were questioned after their travel. It was established that dissatisfaction was effective in the formation of this negativity. In their study, Günlü et al. (2015) interviewed 12 Turkish nationals who have travelled to Armenia and they have determined that the attitudes of the participants who had neutral or positive dispositions towards Armenia changed after their visit, with the outlooks of those with neutral dispositions changing towards positive. In their study, Nyaupane, Teye \& Paris 
(2016) used the survey method on 66 students who have travelled to Australia, Austria, Netherlands, and Fiji and a control group of 80 individuals, and they have determined that there were both positive and negative changes in attitudes towards these countries, and that dissatisfaction was an important factor in the manifestation of negative changes. Amir \& Ben-Ari (1983) carried out a study on 662 Jews who have travelled to Egypt. According to the results of their study, the attitudes of Jews towards Egyptians changed negatively, however, their political attitudes did not change. The personal-social attitudes changed in a positive way while cognitive-competence attitudes changed negatively. Additionally, it was determined that dissatisfaction did not have any relation to the variables. Yilmaz \& Tasci (2014) examined whether social distance attitudes (interested or avoidant) differed in relation to variables, such as previous visits or established close friendships, by making surveys on European tourists who have visited Muğla and the service providing local population. As a result of the study, it was determined that local population's attitudes of interest and avoidance have a positive relationship with the previous visits and established close friendships have negative relationships with both interest and avoidance dimensions. Additionally, in their study Scott-Thomas et al. (2014) have stated that individually visiting tourists may be more effective in decreasing prejudices. Also, in his study Anastasopoulos (1992) have emphasized that, due to limited contact with the local population that occur in organized tours, the resulting attitude changes may be minimal. Therefore, it is believed that attitude changes that result from individual or package tours may be different. Moreover, some studies have determined that the frequency of contact with the local people (Ward \& Berno, 2011) and the number of times visited (Yilmaz \& Tasci, 2014) are factors that are effective in the change of attitudes.

The hypotheses and models that arise from the results of the literature review are as below.

H1: After their travels, the attitudes of tourists change in a statistically significant manner in comparison to their attitudes before traveling

H2: The attitudes of tourists towards the local population who have travelled to a destination is different in a statistically significant manner than the attitudes of those who have never travelled to the same destination.

H3: In terms of the variables of contact with local people (number of arrivals at the destination, the overnights stay at the destination, type of the travel (package or individual)) there is a statistically significant difference in attitude changes.

\section{Methods}

The goals of this study are to determine whether attitudes (prejudice and stereotype) of domestic tourists towards South-easterners change after their travel experiences, whether people who have never visited Southeast have differences in attitude than those who have, and whether the level of contact (number of arrival at the destination, the overnights stay at the destination, type of the travel) with the local people affect the changes in attitude. For this purpose, it was found appropriate to use the survey technique of quantitative research methods.

\subsection{Sampling and Data Collection}

It was aimed to gather surveys from all provinces in order to measure the attitudes towards South-easterners. However, due to the facts that not every province receives 
tourists and that highest concentration of tourists visits the provinces of Gaziantep and Şanliurfa, using the simple random sampling method, domestic tourists who have visited these provinces were requested to fill survey forms. In this context, it was asked of the domestic tourists who have visited the Southeast to indicate their pre-post attitudes, at the end of (during the last day at the destination) vacations. Since asking the same questions at the beginning and after the vacation, coupled with the possible stimulating effects of the previous questions, can render the participants sensitive (Büyüköztürk, 2014: 24), so it was found appropriate to ask the all questions (pre-post) at the same time. Data was gathered from a total of 386 domestic tourists for analysis purposes. Additionally, online methods were used to gather data to form a comparison group from those individuals who have never visited the Southeast. Data was collected from 252 individuals for the comparison group. Special effort was placed on the matter of ensuring similar demographic characteristics in both the comparison group and the domestic tourists.

Approximately $54 \%$ of the participants were female, $76 \%$ were single, $56 \%$ received bachelor's degrees, $43 \%$ stayed only a single night, and $51 \%$ travelled individually. Additionally, the average age is 26 and the average amount that was spent on vacation was 607 TL's. Proportionally similar values are seen in the comparison group. $54 \%$ of the comparison group was female, $84 \%$ were single, $77 \%$ had bachelor's degrees and their average age was 25 .

\subsection{Instrument and Analysis}

Attitude Items: To measure prejudices towards South-easterners, the attitude statements defined by the research of Pizam, Fleischer \& Mansfeld (2002) were used. While preparing the questions, the opinions of three experts were consulted, an ethics committee report was received, and cultural elements of the society were considered. Questions regarding prejudice are made up of 26 statements. It was asked of the participants to answer five of the questions using the Likert scale (1-definitely disagree5-strongly agree).

Demographic and Contact Questions; questions regarding gender, marital status, educational status, and age has been asked. Additionally, to determine the travel experiences and the level of contact with the local population, variables of number stays in the destination, number of arrivals at the destination, and the type of vacation were used.

As a start, the extreme values and incorrectly entered observations were purged from the data. Missing data were filled with average method. As a result, it was deemed appropriate to use 386 of the domestic tourist surveys and 252 of the comparison group (those who never visited southeast) surveys in the analyses. Before moving onto the analyses, multiple normal distribution was considered to test the data quality. Skewness and kurtosis values were taken into consideration when analysing the normality of the data. Since kurtosis and skewness coefficients were between the values of $+2 /-2$ (George \& Mallery, 2010; Schultz \& Gessaroli, 1993), it was determined multiple normal distribution was present and parametric tests could be applied. Results were obtained for the purpose of research by carrying out descriptive statistics, factor analysis, and ANOVA analysis.

\section{Results}


Attitudes obtained from the literature were not subjected to factor analysis. However, the factor analysis was performed on the data in question and the attitude was discussed under two factor analyses. While carrying out factor analyses, attention was paid to ensure that factor load values were over .50, conceptual authenticity was present and KMO value was over .50, while also being attentive to description ratio (Sekeran, 2003). The obtained factor expressions were considered and named.

Table 1 Factor analysis results for attitudes

\begin{tabular}{|c|c|c|c|c|c|}
\hline Factors & Statements & Prejudice & $\begin{array}{l}\text { Positive } \\
\text { Attitude }\end{array}$ & $\begin{array}{c}\text { Cronbach's } \\
\text { Alpha }\end{array}$ & E.T.V. \\
\hline \multirow{14}{*}{ 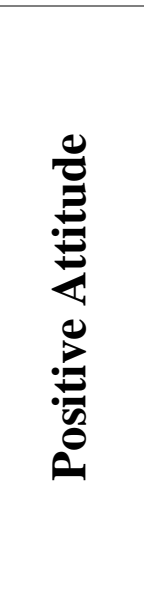 } & They are Positive & ,73 & & \multirow{14}{*}{.90} & \multirow{14}{*}{$15.52 \%$} \\
\hline & They are good & .72 & & & \\
\hline & They are talented & .71 & & & \\
\hline & They are intelligent & ,70 & & & \\
\hline & They are Trustworthy & ,70 & & & \\
\hline & They are respectful & .69 & & & \\
\hline & I like them & ,66 & & & \\
\hline & They act friendly & 64 & & & \\
\hline & They are moral & 64 & & & \\
\hline & They are hospitable & ,63 & & & \\
\hline & They are like me & 63 & & & \\
\hline & They are peaceful & ,61 & & & \\
\hline & They are egalitarians & ,61 & & & \\
\hline & They are polite & 60 & & & \\
\hline \multirow{7}{*}{ 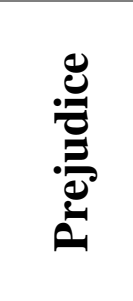 } & They are arrogant & & .71 & \multirow{7}{*}{.78} & \multirow{7}{*}{$30.26 \%$} \\
\hline & They are powerless & & ,68 & & \\
\hline & They are dirty & & ,68 & & \\
\hline & They are crooks & & 66 & & \\
\hline & They are lazy & & ,62 & & \\
\hline & They are cruel & & .58 & & \\
\hline & They are ugly & & ,57 & & \\
\hline
\end{tabular}

Source: own calculations

KMO and Barlett test: KMO: .916/ $\mathrm{X}^{2}: 3142,850 / \mathrm{df}: 210 / \mathrm{p}=.00$,

Explained Total Variance (E.T.V.): 45.79\%. Total C. alpha value: .75

As a result of the factor analysis (see table 1); 5 statements, which had impaired the factor structures, were removed from attitude statements. These attitude statements are comprised of 26 questions and it was noted that explanations can be made using 21 statements and two dimensions. It was determined that factor loads were between .57 and -.73. The first factor, which is comprised of 14 questions, was named the positive attitude because it included positive statements, and the second factor, which is comprised of 7 questions, was named prejudice because it included negative statements. It was determined that the total description rate of the two dimensions was $45.79 \%$, with $30.26 \%$ this percentage of being the prejudice dimension and $15.52 \%$ being the positive attitude dimension. To measure the internal reliability of these dimensions, Cronbach's Alpha values were used. The Cronbach's Alpha value of the prejudice dimension was .79 and Cronbach's Alpha value of the positive attitude dimension was .90. It has been determined total reliability is .75 .

ANOVA analyses were carried out for each of the statements about attitudes. To better observe the differences, instead of making comparisons on a binary basis and applying independent sampling t-tests, One-way ANOVA analysis was preferred, which allows all groups to be compared at once. In the ANOVA analysis, the first thing that was 
checked was whether the variants were equal. In cases where the variants were equal, $\mathrm{F}$ and $\mathrm{P}$ values were checked to determine significance. Bonferroni Post Hoc Test was used to demonstrate the differences between groups in the cases where the variants were equal. In cases where the variants were unequal, however, Welch and $\mathrm{P}$ values were checked to determine the significance of the differences, and Tahmane's T2 Post Hoc Test values were checked to demonstrate the differences between groups.

Table 2 Differences of prejudice and positive attitude according to groups

\begin{tabular}{|c|c|c|c|c|c|c|}
\hline Dimensions & Groups & $\mathbf{N}$ & $\overline{\mathbf{x}}$ & $\mathbf{F}$ & $\mathbf{P}$ & Post-Hoc \\
\hline \multirow{3}{*}{ Prejudice } & $\begin{array}{l}\text { 1. Comparison Group (Non- } \\
\text { visitors) }\end{array}$ & 252 & 3.48 & \multirow{3}{*}{231.80} & \multirow{3}{*}{.00} & $2 / 3$ \\
\hline & 2. Pre-Vacation Prejudice & 386 & 2.22 & & & \\
\hline & 3. Post-Vacation Prejudice & 386 & 2.17 & & & \\
\hline \multirow{3}{*}{$\begin{array}{l}\text { Positive } \\
\text { Attitude }\end{array}$} & $\begin{array}{l}\text { 1. Comparison Group (Non- } \\
\text { visitors) }\end{array}$ & 252 & 3.19 & \multirow{3}{*}{66.23} & \multirow{3}{*}{.00} & $2 / 3$ \\
\hline & $\begin{array}{l}\text { 2. Pre-Vacation Positive } \\
\text { Attitude }\end{array}$ & 386 & 3,59 & & & 3 \\
\hline & $\begin{array}{l}\text { 3. Post-Vacation Positive } \\
\text { Attitude }\end{array}$ & 386 & 3,87 & & & \\
\hline
\end{tabular}

Source: own calculations

The results of the ANOVA analysis (see table 2) have determined that, in the context of the scores that three groups have given to the prejudice and positive attitude dimensions, the comparison group ( $\overline{\mathrm{x}}: 3,48, \mathrm{p}=, 00 / \overline{\mathrm{x}}: 3,19, \mathrm{p}=, 00)$ displays a statistically significant difference in its pre-vacation $(\overline{\mathrm{x}}: 2,22, \mathrm{p}=, 00 / \overline{\mathrm{x}}: 3,59, \mathrm{p}=, 00)$ and post-vacation scores $(\overline{\mathrm{x}}: 2,17, \mathrm{p}=, 00 / \overline{\mathrm{x}}: 3,87, \mathrm{p}=, 00)$. Moreover, the result of the Post Hoc test shows that there are no statistically significant differences between pre-vacation and postvacation scores of the prejudice dimensions. However, it was determined that in the dimension of positive attitude, there is an important difference between pre-vacation and post vacation scores.

Table 3 Differences analysis of attitude differences by the number of overnights stays, type of travel and the number of arrivals at the destination (ANOVA)

\begin{tabular}{|c|c|c|c|c|c|c|}
\hline Groups & Dimensions & & $\mathbf{N}$ & $\overline{\mathbf{x}}$ & $\mathbf{F}$ & $\mathbf{P}$ \\
\hline \multirow{8}{*}{$\begin{array}{l}\text { The number of } \\
\text { overnights Stay }\end{array}$} & \multirow{4}{*}{$\begin{array}{l}\text { Prejudice } \\
\text { Difference }\end{array}$} & 1 night & 169 & -.107 & \multirow{4}{*}{1,31} & \multirow{4}{*}{.27} \\
\hline & & 2 nights & 94 &,- 068 & & \\
\hline & & 3 nights & 32 &,- 026 & & \\
\hline & & 4 nights and + & 91 & ,065 & & \\
\hline & \multirow{4}{*}{$\begin{array}{c}\text { Positive } \\
\text { Difference }\end{array}$} & 1 night & 169 & ,271 & \multirow{4}{*}{,46 } & \multirow{4}{*}{, 70} \\
\hline & & 2 nights & 94 & ,319 & & \\
\hline & & 3 nights & 32 & ,227 & & \\
\hline & & 4 nights and + & 91 & ,234 & & \\
\hline & & & & & $\mathrm{t}$ & $\mathrm{P}$ \\
\hline
\end{tabular}




\begin{tabular}{|c|c|c|c|c|c|c|}
\hline \multirow{4}{*}{ Travel type } & \multirow{2}{*}{$\begin{array}{l}\text { Prejudice } \\
\text { Difference }\end{array}$} & Individual & 200 &,- 041 & \multirow{2}{*}{,- 59} & \multirow{2}{*}{, 55} \\
\hline & & Package & 186 &,- 060 & & \\
\hline & \multirow{2}{*}{$\begin{array}{c}\text { Positive } \\
\text { Difference }\end{array}$} & Individual & 200 & ,255 & \multirow{2}{*}{,- 46} & \multirow{2}{*}{,64 } \\
\hline & & Package & 186 & ,287 & & \\
\hline \multirow{4}{*}{$\begin{array}{c}\text { The number of } \\
\text { arrivals at } \\
\text { destination }\end{array}$} & \multirow{2}{*}{$\begin{array}{l}\text { Prejudice } \\
\text { Difference }\end{array}$} & First Time & 156 &,- 000 & \multirow{2}{*}{1.18} & \multirow{2}{*}{, 23} \\
\hline & & Two or More & 230 &,- 084 & & \\
\hline & \multirow{2}{*}{$\begin{array}{c}\text { Positive } \\
\text { Difference }\end{array}$} & First Time & 156 & ,273 & \multirow{2}{*}{, 73} & \multirow{2}{*}{,94 } \\
\hline & & Two or More & 230 & ,269 & & \\
\hline
\end{tabular}

Source: own calculations

The results of the ANOVA and t-tests demonstrate that (see table 3), in the differences between pre-travel and end of the travel prejudices, positive attitudes and general attitudes, there are no statistically significant differences that are related to the number of arrivals at destination, the type of travel, and the number of overnights stay (p.>0.05).

\section{Discussion and Conclusion}

This study has examined whether the attitudes of domestic tourists, who have visited the provinces of Southeast Anatolia Region provinces of Şanliurfa and Gaziantep, towards South-easterners have changed after their vacations, and if the changes have occurred, whether the type of travel, the amount of time spent, and the number of times visited had any effects on these changes.

The attitude statements used in the study was the single-dimension attitude scale with 26 statements, which was used by Pizam et al. (2002) in their study. As a matter of fact, several other studies such as Pizam, Jafari \& Milman (1991), Milman, Reichel \& Pizam (1990) and Anastasopoulos (1992), which have used similar statements, also made use of a single dimension. However, since the changes in negative and positive attitudes are not the same (Günlü et al. (2015), the attitude scale was considered under the prejudice and positive attitude dimensions. It can be said that there will be a contribution to the literature by this research in this context.

Results of the analyses have shown that prejudices of domestic tourists towards South-easterners have decreased, however, the ANOVA test results have not demonstrated any significances. Additionally, a significant difference was detected between pre-post vacation attitudes of the research group and the comparison group. It has been found that those who have never visited the Southeast have higher levels of prejudice than those who have. In this way, the importance of tourism becomes apparent in this framework. Another important result is, although some positive changes occurred in the attitudes of tourists, these changes were minor. This can be explained with many factors such as characteristics of the destination, personal characteristics of the tourists, etc. This, however, displays the difficulty of changing prejudices. Additionally, it was established that contact variables, which are defined as the number of arrivals at the destination, the number of overnights stay at the destination and the type of travel, had no significant effects on the attitude changes. This situation does not support the hypothesis which claims that increasing the contact between the local population and tourists will 
affect attitudes positively. However, it is well known a fact that contact will not always create a positive change (Stangor, 2009; Cuhadar \& Dayton, 2011).

Examination of the dimension of positive attitude demonstrates in a statistically significant manner that positive attitudes of the comparison group are lower than the positive attitudes of visiting tourists' group and post-vacation positive attitudes of the visiting tourists have improved in comparison to their pre-vacation positive attitudes. This supports a hypothesis stated in the literature, which claims that positive attitudes can be changed more easily. Additionally, it was determined that factors of amount of times the destination is visited, amount of nights spent at the destination and the type of travel, which are defined as the contact variables, did not affect the differences in positive attitude.

As a result of the research, hypotheses of "H1: After their travels, the attitudes of tourists change in a statistically significant manner comparison to their attitudes before traveling" and "H2: The attitudes of tourists towards the local population who have travelled to a destination is different in a statistically significant manner than the attitudes of those who have never travelled to the same destination" were accepted. However, the hypothesis of "H3: In terms of the variables of contact with local people (the number of arrivals at destination, the, the number of overnights stay and type of travel (package or individual)) there is a statistically significant difference in attitude changes. " was denied.

Some aspects of the results are supported by the literature while some are not. Similar to other studies (Uriely, Maoz \& Reichel, 2008; Gill et al., 2015; Chen, 2010; Scott-Thomas et al., 2014) have determined that tourism changes attitudes in positive or negative ways. Likewise, in studies which have focused on the comparison groups (Pizam et al., 1991; Nyaupane et al., 2016), it was determined that those who have never visited the destination could have more negative or positive attitudes in comparison to those who have. Furthermore, the conclusion that there are no differences in attitude changes due to contact variables is similar to the studies of Yilmaz \& Tasci (2014) and it is in contrast with the studies of Ward \& Berno (2011). Since variables such as the personality type of the tourists, the satisfaction derived from the destination, the effects of the tour guide, historical ties between two communities, and the intensity of the prejudice can affect the attitude changes, it is possible to arrive at different conclusions than previous researches.

As a result of the research, some application suggestions have been developed for the sector. First, stakeholders in the tourism sector need to act in awareness of the effects that tourism has on economic, environmental, socio-cultural impacts as well as on reducing prejudices, discrimination, and hostilities. It is believed that, if this awareness is created, local shop owners and local populations will start acting more carefully against tourists, which will, in turn, increase the satisfaction of tourists. Destination managers should calculate the tourist capacity of their destinations and make temporal distributions based on the number of tourists. Otherwise, the dissatisfaction of amassed tourists may cause the existing attitudes to grow even more negative.

By taking mutual steps towards each other, states or societies that are prejudiced against each other can use tourism as a tool to increase touristic mobility, improve intersocietal contact and communication, and reduce prejudices between each other. It is believed that the existing social problems can be reduced to some extent through this method. At this point, the Ministry of Culture and Tourism can realize various projects (tax breaks per tour or monetary support) in order to reduce the prejudices against the Southeast region, which would have the effect of revitalizing the tourism in the region. Thus, the welfare level of the Southeast Anatolia Region, which is lagging behind in 
regional development, will be increased and contributions will be made to social peace by the way of tourism.

Initially, it was planned to focus the research on four provinces which receive the highest amounts of tourists in the Southeast Anatolia Region. However, due to the drop in the tourist visitations to other provinces during the research, only two provinces could be included in the study. This is considered to be a limitation of this research. However, as a result of the observations of the researches and interviews made with tourism guides, it was concluded that similar results could be obtained in the other provinces.

Apart from this limitation, the fact that only domestic tourists were included in the research is also an important limitation. The reason for this is that the number of foreign tourists visiting in the region is very low and the difficulties that have arisen in contacting them. Additionally, the fact that visiting tourists prefer to stay for short durations is an obstacle in determining whether the prejudices are changing in the long-term or not. Furthermore, the scale form that was used in the research was filled by tourists on their last day of vacation and they were questioned about their views before and after their vacation. However, by cooperating with tourism firms, different time-frames such as before arriving at the destination, just after leaving the destination, and a long time after the vacation it could be researched and compared. Moreover, researches that focus on the attitudes of the local population towards visiting domestic tourists and their cultural differences could benefit the understanding of this subject.

\section{References}

1. Ajanovic, E., Çizel, B., \& Çizel, R. (2016). Effectiveness of Erasmus Programme in prejudice reduction: Contact theory perspective. The Business of Tourism, 17, 47-60.

2. Allport, G. W. (1954). The nature of prejudice. USA: Perseus Book Publishing.

3. Amalu, T. E., Otop, O. O., Duluora, E. I. Omeje, V.U., \& Emeana, S.K. (2018). Socio-economic impacts of ecotourism attractions in Enugu state, Nigeria, Geojournal, 83, 1257-1269. doi.org/10.1007/s10708-017-9830-7.

4. Amir, Y., \& Ben-Ari, R. (1983). Cognitive cultural learning, intergroup contact and change in ethnic attitudes and relations. Paper presented at the International Conference on Group Processes and Intergroup Conflict, Israel.

5. Anastasopoulos, P. G. (1992). Tourism and attitude change: Greek tourists visiting Turkey. Annals of Tourism Research, 19(4), 629-642.

6. Aronson, E., Wilson, T. D., \& Akert, R. M. (2012). Sosyal psikoloji. (O. Gündüz, Çev.). İstanbul: Kaknüs Yayınları. [Aronson, E., Wilson, T. D., \& Akert, R. M. (2012). Social psychology, İstanbul: Kaknüs Publications.

7. Büyüköztürk, Ş. (2014). Deneysel desenler, Ankara: Pegem Akademi Yayıncılık. [Büyüköztürk, Ş. (2014). Experimental designs, Ankara: Pegem Academi Publishing].

8. Çelik, S. (2018). Does tourism reduce social distance? A study on domestic tourists in Turkey. Anatolia, 1(2), 1-12. doi: 10.1080/13032917.2018.1517267.

9. Çelik, S., \& Uygur, N. (2017). An evaluation of the impacts of international political crises on Turkish tourism. In Efe, R. Penkova, R., Wendt, J. A., Saparov, K.T., Berdenov, J.G. (Eds.), Developments is social sciences, (pp. 623-631), Sofia: St. Kliment Ohridski University Press.

10. Chen, C. M. (2010). Role of tourism in connecting Taiwan and China: Assessing tourists' perceptions of the Kinmen-Xiamen links. Tourism Management, 31(3), 421-424. 
11. Choi, O., Lee, K., Lee, K., \& Kim, J. (2017). Influences of stereotype and social distance on prejudice toward African Americans. Journal of Psychology in Africa, 27 (1), 13-17, doi: 10.1080/14330237.2016.1268262

12. Cuhadar, E., \& Dayton, B. (2011). The social psychology of identity and intergroup conflict: From theory to practice. International Studies Perspectives, 12, 273-293.

13. Fan, D. X.F., Zhang, H. Q., Jenkins, C.L., \& Lin, P.M.C. (2017). Does touristhost social contact reduce perceived cultural distance? Journal of Travel Research, 56(8), 1-13.

14. Farmaki, A. (2017). The tourism and peace nexus. Tourism Management, 59, 528540

15. Fishbein, M., \& Ajzen, I. (1975). Belief, attitude, intention, and behaviour: An introduction to theory and research. MA Addison Wesley: Reading.

16. George, D., \& Mallery, P. (2010). SPSS for Windows step by step. A simple study guide and reference.

17. Grothe, J. (1970). Attitude change of American tourists in the Soviet Union (Doctorate dissertation). The George Washington University, Washington, DC.

18. Günlü, E., Özgen, H. K. Ş., Dilek, S. E., Kaygalak, S., Türksoy, S., \& Lale, C. (2015). Turkish visitors in Armenia: Any changes in attitudes and perceptions? Journal of Tourism and Hospitality Management, 3(1), 29-43

19. Hogg, M., \& Vaughan, G. (2007). Sosyal psikoloji. (Translaters: İ. Y1ldız \& A. Gelmez) Ankara: Ütopya Yayınevi. [Hogg, M., \& Vaughan, G. (2007). Social psychology, Ankara: Ütopya Publishing].

20. Hortaçsu, N. (2012). En güzel psikoloji sosyal psikoloji. Ankara: İmge Kitabevi. [Hortaçsu, N. (2012). The most beautiful psychology social psychology. Ankara: İmge Publisher].

21. Jain, V. (2014). 3D model of attitude. International Journal of Advanced Research in Management and Social Sciences, 3(3), 1-12.

22. Kağıtçıbaşı, Ç., \& Cemalcılar, Z. (2014). Dünden bugüne insan ve insanlarSosyal psikolojiye giriş. İstanbul: Evrim Yayınevi [Kağıtçıbaşı, \& Cemalcılar (2014). Human and people from past to present-introduction to social psychology, İstanbul: Evrim Publisher].

23. LaPiere, R. T. (1934). Attitudes vs. actions. Social forces, 13(2), 230-237.

24. Milman, A., Reichel, A., \& Pizam, A. (1990). The impact of tourism on ethnic attitudes: The Israeli-Egyptian case. Journal of Travel Research, 29(2), 45-49.

25. Minard, R. D. (1952). Race relationships in the Pocahontas coal field. Journal of Social Issues, 8(1), 29-44.

26. Ming, H. (2018). Cross-cultural differences and cultural stereotypes in tourism Chinese tourists in Thailand, Journal of Hotel \& Business Management, S1: 001. doi: 10.4172/2169-0286.S1-001.

27. Nyaupane, G. P., Teye, V., \& Paris, C. (2016). Tourism and attitude change: The case of study abroad students, Tourism Travel and Research Association: Advancing Tourism Research Globally. Paper 64.

28. Pearce, P. L. (1980). A favorability-satisfaction model of tourists' evaluations. Journal of Travel Research, 19(1), 13-17.

29. Pizam, A., Fleischer, A., \& Mansfeld, Y. (2002). Tourism and social change: The case of Israeli ecotourists visiting Jordan. Journal of Travel Research, 41(2), 177184. 
30. Pizam, A., Jafari, J., \& Milman, A. (1991). Influence of tourism on attitudes: US students visiting USSR. Tourism Management, 12(1), 47-54.

31. Pong But, J. W., \&Ap, J. (2017), The impacts of casino tourism development on Macao residents' livelihood, Worldwide Hospitality and Tourism Themes, 9 (3), 260-273.

32. Pratt, S., \& Liu, A. (2015). Does tourism really lead to peace? A global view. International Journal of Tourism Research, 18(1), 82-90.

33. Schutz,R.W., \& Gessaroli, M.E. (1993). Use, misuse, and disuse of psychometrics in sport psychology research. In R.N. Singer, M. Murphey \& L.K. Tennant (Eds.), Handbook of research on sport psychology (pp. 901-917). New York: Macmillan.

34. Sekeran, U. (2003). Research methods for business: A skill building approach (Fourth Edition). USA: Hermitage Publishing Services.

35. Sirakaya-Turk, E., Nyaupane, G., \& Uysal, M. (2014). Guests and hosts revisited: Prejudicial attitudes of guests toward the host population. Journal of Travel Research, 53(3), 336-352.

36. Stanciu, A., \& Vauclair, C. M. (2018). Stereotype accommodation: A sociocognitive perspective on migrants' cultural adaptation. Journal of Cross-Cultural Psychology, 49(7), 1027-1047.

37. Stangor, C. (2009). The study of stereotyping, prejudice, and discrimination within social psychology: A quick history of theory and research. In T. Nelson D. (Ed.), Handbook of prejudice, stereotyping, and discrimination (pp. 1-22). New York.

38. Tomljenovic, R. (2010). Tourism and intercultural understanding or contact hypothesis revisited. In O. Moufakkir \& I. Kelly (Eds.), Tourism, progress and peace (pp. 17-34). CABI.

39. UNWTO, (2018). Tourism highligts, https://www.e unwto.org.

40. Uriely, N., Maoz, D., \& Reichel, A. (2009). Israeli guests and Egyptian hosts in Sinai: A bubble of serenity. Journal of Travel Research, 47(4), 508-522.

41. Ward, C. \& Berno, T. (2011). Beyond social exchange theory-attitudes toward tourists. Annals of Tourism Research, 38(4), 1556-1569.

42. Wintersteiner, W., \& Wohlmuther, C. (2014). Peace sensitive tourism: How tourism can contribute to peace. In Wohlmuther, C. \& Wintersteiner, W. (Eds.), International Handbook on Tourism and Peace (pp.31). Avusturya: Drava.

43. Yilmaz, S. S., \& Tasci, A. D. (2015). Circumstantial impact of contact on social distance. Journal of Tourism and Cultural Change, 13(2), 115-131.

44. Zaei, M. E., \& Zaei, M. E. (2013). The impacts of tourism industry on host community, European Journal of Tourism Hospitality and Research, 1(2), 12-21.

\section{Brief description of Author:}

\section{Sedat Çelik}

Assistant Professor at Hospitality Management in the School of Tourism and Hotel Management at Şırnak University. Şırnak University/Mehmet Emin Acar Campus, School of Tourism and Hotel Management, Şırnak/Turkey. His research interests include destination marketing, hotel management, and the social psychology of tourism.

s.celik@sirnak.edu.tr, sedattcelik@gmail.com 